\title{
Slkolehelsetjenesten. Vennskap
}

\section{blant barn er viktigere enn vi tror.}

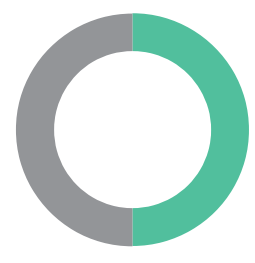

DOI-NUMMER:

10.4220/sykepleiens.2014.0131

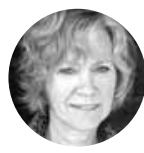

Liv Tønjum, Fagutvikler og prosjektlederSolheimsviken Solheims Bergen kommune. Forlagsredaktør i Fagbokforlaget fra august 2014.

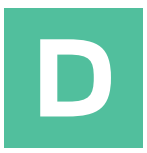
enne artikkelen bygger på tiåringers egne uttalelser i fokusintervjuer gjennomført høsten 2012 i Årstad bydel i Bergen. Fokusintervjuene var en del av prosjektet «Vennskap mot mobbing» støttet av Helsedirektoratet gjennom Manifest mot mobbing (1).

FREMGANGSMÅTE. To helsesøstre gjennomførte fire intervjuer med åtte til ti barn fra femte trinn på fire ulike barneskoler, til sammen 35 barn av begge kjønn og blandet etnisk opprinnelse. Hvert intervju varte fra en til en og en halv time og ble gjennomført i skoletiden. Alle elevene deltok med samtykke fra foreldre. Vi brukte en mal med åpne spørsmål om vennskap, trivsel, skolemiljø og mobbing eller plaging. En strektegning hentet fra boken Sammen så det hjelper (2) ble brukt som inngangsport til samtalen med barna. Intervjuene ble tatt opp på bånd, skrevet av ord for ord og deretter ble opptakene slettet. Det ble ikke brukt navn i løpet av intervjuene eller ført navnelister med personalopplysninger. Undersøkelsen ble registrert i Datatilsynet mai 2012.

Etterbehandlingen og tolkningen av intervjusvarene er inspirert av Grounded Theory (GT). Å gjennomføre en undersøkelse ved hjelp av denne metoden ville kreve mer tid og ressurser enn det kommunehelsetjenesten kan stille opp med. Men jeg er fascinert av grunntanken i GT som hevder at mennesker er rasjonelle i forhold til utfordringer og problemer de møter i livet, og om hvordan samhandling og relasjoner virker inn på folks liv. GT egner seg godt til denne type forskning (3).

Et poeng med denne undersøkelsen var å la barna selv komme til orde. Det er i tråd med offentlige føringer og ideen om brukerstyrte tjenester, men det er ikke alltid fagfolk faktisk gjør det. Vi ble selv litt overrasket over hvor bra respons vi fikk. Uttalelser som: «Jeg har litt god samvittighet nå for å si det jeg mener, og hvordan jeg har det her på skolen». "Helt seriøst, kan vi si det vi vil? Skal vi ikke snakke etter papiret?»

HVA ER VENNSKAP? Professor Anne Inger Helmen Borge sier at vennskap mellom to barn karakteriseres av gjensidighet. Begge parter i vennskapet skal oppfatte den andre som sin venn. Vennskap bygger på en sterk følelsesrelasjon utenom tid og rom, alder, kjernefamilie eller klasse. Byggesteinen i vennskap er personlige egenskaper hos barnet og hos den barnet velger som venn. Små barn helt ned i to års alder kan peke ut andre barn de ønsker å være venner med og velge andre bort. Borge skiller mellom vennskap, jevnaldringsrelasjoner og popularitet. For å få en venn kreves det prososial atferd, det vil si at barnet for eksempel kan dele, trøste og hjelpe andre (4). Popularitet dreier seg mer om å være likt og akseptert innenfor gruppen. Vennskap kan også benyttes på gruppenivå sier Øyvind Kvello (5) og nevner begrepene klikk og flokk som subgrupper av diffuse jevnaldringsgrupper. Noen ganger kan tette vennskap, såkalte dyader, være negative.

\section{VENNSKAP BLANT TIÅRINGER.} Barna i denne undersøkelsen gir mange eksempler på hva gode venner gjør sammen; de leker, har det gøy, prater sammen, driver med radiostyrt bil, går i butikken, går på trening sammen, hopper på trampoline, de er hjemme hos hverandre, har putekrig, spiser middag hos hverandre, går på loppemarked, ser tv sammen og holder på med data og så videre. Overnatting er tegn på virkelig vennskap, likeledes å bli invitert med på middag, hyttetur eller ferier. To gutter sier at de har vært venner fra barnehagen. En annen forteller at han skyper med bestekompisen, som har byttet skole, nesten hver dag. Og at de også brevveksler for da kan de sende hverandre gaver.

EN GOD VENN. Å være en god venn var et av hovedtemaene i intervjuene. En god venn er ensbetydende med å være empatisk (se figur 1). En
Fakta 000

Hoved-

budlskap

10-åringene i denne fokusgruppeundersøkelsen er opptatt av «å venne». De vedlikeholder, revitaliserer, utvider eller inkluderer vennerelasjonene kontinuerlig. Deønsker seg ansvarlige og lyttende voksne som er flinke til å ta opp problemenenår de oppstår. Tydelige regler på skolen, samt trygghet i miljøet like utenfor skolen, er billige tiltak for barns psykisk helse.

\section{Nølkkelord}

Les mer og finn litteraturhenvisninger på vår nettsider.

- Barn

- Psykisk helse

- Skolehelsetjeneste 


\section{Å vaere en god venn}

\begin{tabular}{|l|}
\hline Å være \\
empatisk \\
- er der alltid for deg \\
- når foreldrene dine ikke \\
forstår deg \\
- setter seg inn i andres \\
situasjon \\
- forstår hvordan du har det \\
\end{tabular}
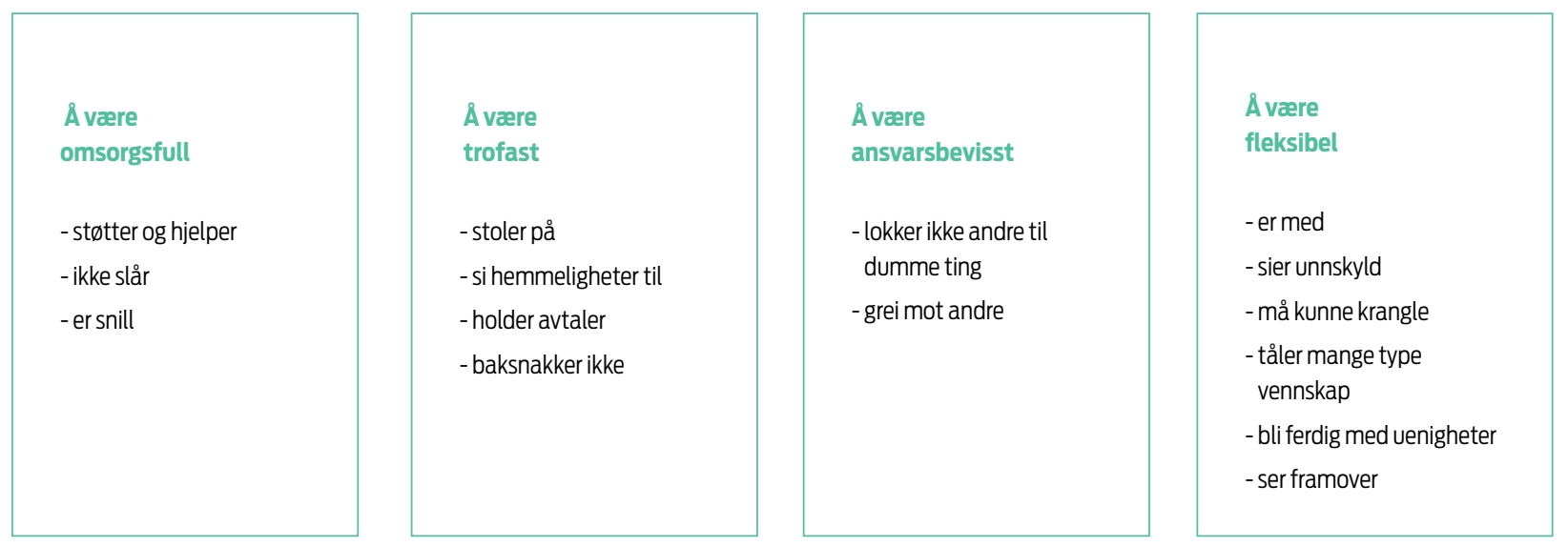

venn er en som forstår hvordan du har det, en som alltid er der for deg eller som kan sette seg inn i andres situasjon. «Det er fint å ha en venn når foreldrene dine ikke forstår deg». Barna i intervjuet snakket om å være snille, om å støtte og hjelpe hverandre. «En god venn skal ikke plage andre venner som du har». Alle gruppene tematiserte venners lojalitet. De karakteriserte nære venner som trofaste og ansvarsbevisste. «En venn bør ikke avlyse avtaler sånn plutselig, og de skal være snille mot alle andre og holde på hemmeligheter».

Å være en god venn krever også at man er fleksibel. På flere av skolene var det utviklet et klima for fleksible grupper barna kunne komme inn og ut av etter eget ønske. Hovedregelen var at alle skulle få være med og at det var ikke lov å si nei hvis man ble invitert med i en lek eller aktivitet. «Det går ikke an å si nei hele tiden.»

"Å VENNE.» Barna i denne fokusgruppeundersøkelsen var opptatt av det å være venner, her verbalisert til «å venne» (se figur 2, neste side). Det viktigste for disse tiåringene er simpelthen «å venne». Å venne handler om det å vedlikeholde, å revitalisere, å utvide eller inkludere vennskap. Implisitt i dette konseptet ligger også det å ikke mobbe andre. Barna vi snakket med hadde en tydelig motivasjon for å ha et godt forhold til venner. «Det er dumt for barn å være uvenner.» «Hvis det er en vennegruppe, må vi passe på at alle har det gøy. Prøve å få alle med i leken». «Jeg vil ikke det skal være så mye mobbing på skolen, det blir ikke noen god skole av det.»

Barna vedlikeholder vennskap ved å støtte, hjelpe og oppmuntre hverandre. De syntes det var viktig å holde avtaler og å kunne holde på hemmeligheter. Vennskap blir hele tiden revitalisert fordi de ofte krangler, blir uvenner og deretter blir de venner igjen. Gode venner skal tilgi hverandre. Noen hevder

\section{«Det går ikke an å si nei hele tiden.»}

at det å krangle er en del av vennskapet. En gutt sa at man trengte ikke være bestevenner hele tiden, mens jentene snakket om tettere bestevennallianser.

KLASSE- OG SKOLEMILJØET. Vi fikk ulike reaksjoner da vi spurte om miljøet i klassen. En gruppe var godt fornøyd noe de forklarte på denne måten: «Vi leker bomgjemsel nesten hele klassen, det er blitt en tradisjon etter at vi hadde sånn aktiv dag. Tror det er det mest aktive vi har gjort».

«Vi i klassen er gode kompiser. I klassen vår er det ingen som er alene. Vi er gode til å spørre om vi skal være med dem. Det er mange forskjellige grupper og alle er trukket med i dem. Alle er med noen. Det er på en måte grupper, men det er ikke det at vi utestenger andre ... Kaller det grupper for det er de som nesten alltid er sammen. Alle får lov til å bli med. Vi er forskjellige, og da er det litt vanskelig å være med dem som for eksempel liker fotball mens vi liker å leke.»

Vi merket oss at barna på en skole brukte ordet grupper i stedet for gjenger. De gangene gjenger ble brukt av ungene, hadde det en mer negativ 


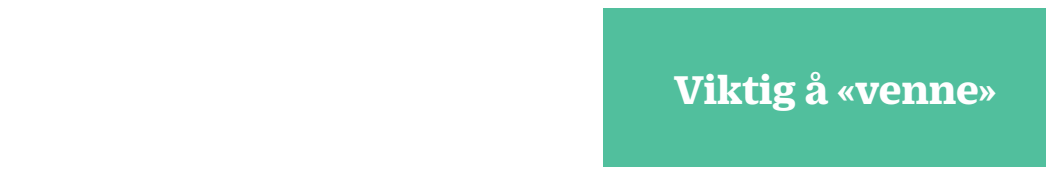

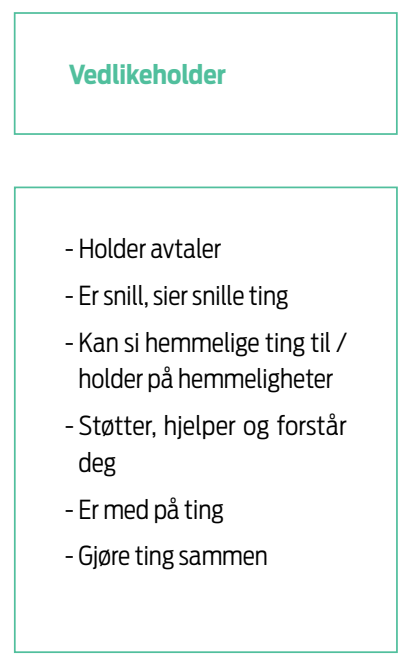
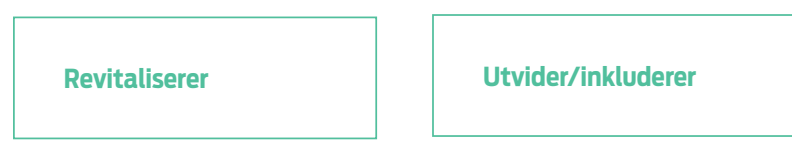

-Krangler og blir venner igjen

- Lekekrangler

- Må kunne gi seg

- Trenger ikke være bestevenner hele tiden

- Sier unnskyld og ordner opp

- Tilgir hverandre

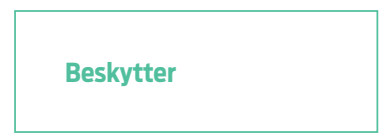

Er grei med andre

- Setter seg inn i andres situasjon

- En som ikke finner på noe dumt og drar andre med seg

- Baksnakker ikke

- En som man kan stole på klang. Grupper var åpne, gjenger var mer lukket. «Tomannscup» ble ofte nevnt, det betyr leker med kun to deltakere. Det kan tolkes som en lovlig måte å stenge andre ute på, dette gjelder mest jenter.

«Det er bra i klassen. Det er litt krangling, ikke alvorlig. Vi arbeider veldig bra. Det som er bra med klassen, er at vi holder sammen og er snille med hverandre. Hvis vi krangler, pleier vi å roe oss ned etter en stund. Så er vi ganske greie med hverandre og så deler vi med hverandre, gir hverandre komplementer, ingen truer noen her».

«Læreren vår er litt streng. Vi må gjøre ting nøyaktig og hvis ikke må vi gjøre alt en gang til. Og så må vi ofte ut på gangen hvis vi ... Læreren er egentlig en av de strengeste på skolen, men det er bra. Da får vi masse til. Hun er en skikkelig god lærer, den beste læreren jeg har hatt faktisk.»
Noen grudde seg til skolen og snakket om det under intervjuet. En sa: «Jeg gruer meg litt fordi noen av vennene mine er litt sånn egoist, de er rike, har mye penger og sånn, de er litt sånn diva, de sier hva vi skal gjøre og sånn». Denne eleven skilte seg klart ut fra de andre.

KONFLIKTER. Flere av barna vi intervjuet snakket om at de ofte kranglet, lekeslåss, slåss og ble uvenner. «Stort sett er vi venner, men det kommer litt an på ( $\mathrm{hm}$, hm). Man må i alle fall ikke slåss». Krangling var noe de var vant med. De mente man kunne ordne opp ved å unnskylde seg eller ved å bli ferdig med uenigheten.

Samtlige grupper nevnte ballbingen, gymmen og stangen som steder hvor de opplevde knuffing; slåing, sparking og konflikter blant elevene. Flere grupper var opptatt av de minste barna på skolen for de mente de minste ikke alltid fikk den beskyttelsen de trengte. Noen skoler hadde ikke opprettet fadderordninger eller andre tiltak som for eksempel eget område på skoleplassen for de minste. Flere grupper var redde for de eldste; sjuende- eller tiendeklassingene. Løsningen var å unngå dem eller løpe redd hjem fra skolen når de ble plaget. Alle synes det var uakseptabelt, men de klarte ikke å få lærerne til å gjøre noe med det.

I følgende sitat snakket barna om en situasjon når tre elever ville leke en ting, men den fjerde ikke ville det. «Tre mot en, da gjør vi det de fleste vil. Da måtte han gi seg, eller komme med et bedre forslag. Det er mer rettferdig sånn at de tre får leke. Vi kan stoppe opp leken, 


\begin{tabular}{|l|}
\hline Dette fremmer «venningen » \\
- Trygghet \\
- Aktivt arbeid med skolemiljø \\
- Tydelige regler \\
- Gode systemer/tiltak \\
- De eldste deltar positivt \\
- Ansvarlige voksne \\
- Klassemiljø \\
- «Alle skal med»-holdning \\
- Bevisst konflikthåndtering \\
Trygg og bestemt klassekontakt \\
- Vennegrupper \\
- Åpne familier \\
\end{tabular}

om tre leker sammen og en ikke vil være med, for å finne ut om vi kan gjøre noe slik at den fjerde får lyst til å være med. Av og til må man leke noe som ikke er så veldig gøy. Vi kan heller bytte på hvem som skal bestemme».

REGLER. «Vi har regler som læreren har laget. I fjerde klasse kranglet vi mye. Vi er enige i reglene og vi følger de, vet ikke om alle er enige.»

Barna sa at de likte regler og lærere som var forutsigbare og som hjalp dem med trivsel og trygghet i klassen. De ønsket seg ansvarlige og lyttende voksne som var flinke til å ta opp problemene når de oppsto: «De voksne må ikke vente for lenge, men gjøre det med en gang. En lærer han sier sånn; Jaja, det får gå for denne gangen. Neste gang sier de det samme, men så skjer det jeg skulle hjem, da satt det noen menn på haugen, de ville vite hva klokken var og de ville jeg skulle komme opp til dem og vise klokken, men jeg ble redd og løp hjem. Politiet har vært på skolen for å advare elevene."

«Jeg er veldig redd han for det var en narkoman som sa til meg; din drittunge, pell deg vekk fra området her. Og sånn, din lille hore."

«Det bor en narkoman ved butikken, han har en kjempestor hund som alltid snuser mot meg. Det liker jeg ikke, da blir jeg redd. Da tror jeg den vil bite meg. Når jeg ser ut av vinduet, ser jeg hele tiden den stakkars hunden som står utenfor. Han lufter ikke hunden, det er bare for å røyke. Den får aldri en tur.»

Skolene vil muligens hevde at de ikke kan gjøre noe med beliggenhet og belastete nærmiljøer, men det er likevel et tankekors at man beskytter skolebarn mot farlig trafikk, men ikke mot sjikane og truende oppførsel fra voksne i nærmiljøet rett utenfor skolen.

DISKUSJON. Barna som deltok i fokusgruppeintervjuene, foreslo selv flere gode løsninger for den viktige venningen. Tabellen over viser det som fremmer og det som hemmer et godt skolemiljø, og som forebygger mobbing og plaging av elever (se tabell 1).

I samtalene med tiåringene $\mathrm{i}$ Årstad la vi mest vekt på å snakke om det positive med vennskap, men de beskrev også negative aspekter. Det kan være konkurranse, konflikter, utnytting, sjalusi, misunnelse og bedrag. Flere snakket om andre som ble offer for slem og uvettig bruk av sosiale medier og mobiltelefon. Vennskap kan bestå av relasjoner hvor både mobber og mobbeoffer inngår. Å velge lag er noe som lett skaper tapere, dette var noe elevene tok opp i en av gruppene.

Barna trekker inn foreldrene og familien når de ønsker å løse problemer de kommer opp i. Med åpne familier menes her (se tabell 1) foreldre med en demokratiserende oppdragerstil i motsetning til lukkete familier. Et eksempel på lukkete familier kan være når foreldre aldri deltar på skolearrangementer eller møter.

VENNSKAP VIKTIG. For alle barn er vennskap helt nødvendig for trivsel, for å føle seg verdsatt og for god psykisk helse. Fagfolk i skolen og foreldre kan bidra med å hjelpe barn til «å venne» og for å oppnå mobbefrie miljøer i skolen. Helsesøstre i skolehelsetjenesten kan arbeide for å avdekke utstøtte, redde og ensomme barn ved å spørre barn direkte og bringe temaet på bane. Barn som utsettes for mobbing eller uheldige episoder i skoletiden, forteller ikke foreldre eller andre voksne om hva de blir utsatt for, hevder forskerne i Ulweus-programmet.

«Det er mange som blir redde på skolen, men når de kommer hjem til foreldrene tør de ikke å si det for de (foreldrene) blir så redde. Så spør foreldrene hva som har skjedd på skolen i dag, og da sier de (barna) ingenting. Og så går de og tenker på det, i stedet for å si det til foreldrene. Det har jeg faktisk gjort.» «Det har jeg også gjort, sier en annen.»

Det er livsviktig for barn at det fins ansvarlige voksne som er åpne og handlingsvillige ovenfor barns problemer og at vi har gode systemer som fremmer vennskap i skolen. $\bullet$

\section{REFERANSER:}

1. Manifest mot mobbing 2011-2014. Et forpliktende samarbeid for et godt og inkluderende oppvekst og læringsmiljø. Helsedirektoratet.

2. Eide G, Rodhe R. Sammen så det hjelper. Bergen: Fagbokforlaget, 2009.

3. Lomborg K. Om grounded theory- hvad det er og ikke er. Klinisk sykepleje 2005; 19:4-11.

4. Borge, Anne Inger Helmen: Vennskap. Skolepsykologi in. 4 2009.

5. Kvello $\emptyset$. Barns og unges vennskap. Doktoravhandling. NTNU 2006.

\section{FAGARTIKLER:}

Fagartikler kan sendes til torhild.apall@sykepleien.no 